\title{
MORPHOLOGY AND GENETIC DIVERSITY OF MITOCHONDRIAL DNA D-LOOP REGION USING PCR-RFLP ANALYSIS IN MAGELANG DUCK AND OTHER NATIVE DUCK
}

\author{
D. Purwantini ${ }^{1, *}$, T. Yuwanta ${ }^{1}$, T. Hartatik ${ }^{1}$ and Ismoyowati $^{2}$ \\ ${ }^{1}$ Faculty of Animal Science, Gadjah Mada University, \\ Jl. Fauna 3, Bulaksumur Yogyakarta 55281 - Indonesia. \\ *Permanent Address: Faculty of Animal Science, Jenderal Soedirman University, \\ Jl. Dr. Soeparno No. 60, Kampus Karangwangkal, Kotak Pos 110 Purwokerto 53123 - Indonesia \\ ${ }^{2}$ Faculty of Animal Science, Jenderal Soedirman University, \\ Jl. Dr. Soeparno No. 60, Kampus Karangwangkal, Kotak Pos 110 Purwokerto 53123 - Indonesia \\ Corresponding E-mail: dattadewi2002@yahoo.com
}

Received December 22, 2012; Accepted February 07, 2013

\begin{abstract}
ABSTRAK
Penelitian ini bertujuan untuk mengetahui pengaruh warna bulu yang berbeda terhadap keragaman morfologi itik Magelang dan keragaman genetik menggunakan analisis PCR-RFLP daerah D-loop DNA mitokondria (mtDNA) pada populasi itik Magelang dan itik lokal lainnya (itik Tegal, Mojosari, Bali dan Alabio) di Indonesia. Materi penelitian terdiri atas itik Magelang sebanyak 50 ekor dan itik lokal lainnya masing-masing 20 ekor yang diambil sampel darahnya. Karakteristik morfologi ukuran tubuh, kemampuan produksi maupun kualitas telur itik Magelang dianalisis menggunakan rancangan acak lengkap dengan sebelas macam warna bulu yang berbeda sebagai perlakuan. Teknik PCR digunakan untuk mengamplifikasi fragmen pada daerah $D$-loop mtDNA dan produk PCR didigesti dengan menggunakan enzim restriksi endonuklease AluI and HaeIII. Penelitian ini berhasil menunjukkan bahwa secara statistik keragaman morfologi pada populasi itik Magelang dipengaruhi oleh perbedaan warna bulu. Analisis PCR-RFLP menggunakan enzim restriksi AluI and HaeIII berhasil memperoleh enam kombinasi pola restriksi fragmen, sehingga dihasilkan enam haplotipe (A, B, C, D, E and F). Perbedaan haplotipe tersebut menunjukkan adanya keragaman genetik pada populasi itik Magelang dan itik lokal lainnya. Disimpulkan bahwa perbedaan warna bulu mempengaruhi keragaman morfologi pada populasi itik Magelang dan keragaman genetik populasi itik lokal di Indonesia dapat diidentifikasi menggunakan analisis PCR-RFLP pada daerah $D$-loop mt DNA.
\end{abstract}

Kata kunci: keragaman morfologi, genetik, PCR-RFLP, D-loop mtDNA, itik Magelang

\section{ABSTRACT}

The aim of this study was to investigate the different of plumage colors on morphological diversity of Magelang duck and genetic diversity using PCR-RFLP mtDNA D-loop region analysis of Magelang duck and four others native duck population (Tegal, Mojosari, Bali and Alabio duck) in Indonesia. Blood sample was taken from 50 Magelang ducks and 20 of each native ducks. Morphological characteristics of body measurement, production ability and egg quality of Magelang duck were analyzed using Completely Randomized Design with 11 plumage colors as treatments. PCR technique was administered to amplify fragments in mtDNA D-loop region and PCR products were digested with endonuclease restriction enzyme AluI and HaeIII. The result showed that morphology diversity of Magelang duck was statistically affected by different plumage colors. PCR-RFLP analysis using AluI and HaeIII restriction enzyme resulted in six combinations of restriction fragment pattern shown in six haplotypes $(\mathrm{A}, \mathrm{B}, \mathrm{C}, \mathrm{D}$, $\mathrm{E}$ and F). Haplotype difference showed genetic diversity in the population of Magelang duck and the other native ducks. In conclusion, the different plumage colors affected morphology diversity of Magelang duck. Genetic diversity of Indonesian native duck population could be identified by using PCR-RFLP analysis on mtDNA D-loop region.

Keywords: morphology diversity, genetic, PCR-RFLP, mtDNA D-loop, Magelang duck 


\section{INTRODUCTION}

Magelang duck is native duck thriving in Muntilan, Magelang, Central Java province with specific and ultimate morphological characteristics of relatively big body, high egg production and various plumage color Ismoyowati and Purwantini (2010) reported that Magelang duck qualitatively has the highest plumage color diversity compared to other native duck.

Individual genetic variation within population is the figure of the heritable genetic expression variation. Genetic expression is the characteristic possessed by an individual as distinctive morphological feature. Through DNA marker diversity analysis on protein or enzyme, individual genetic diversity within and between population can be identified (Sakai et al., 1998). One of the analysis methods to identify genetic in several fowl species applies Polymerase Chain Reaction-Restriction Fragment Lenght Polymorphism (PCR-RFLP) (Herman, 2004; Sartika, 2007). Mitochondrion DNA lies outside the nucleus in one cell compartment or organelle named mitochondrion (Zhao et al., 2004), with higher mutation rate (5-10 times) than DNA nucleus (Parsons et al., 1997; Brown et al., 1979; Siguroardóttir et al., 2000 in Sudoyo, 2004), so it has high discrimination ability (Marzuki, 2004). Likewise, there are one closed circular area with complete necluotide sequence and one non coding region called displacement loop (D-loop) measuring $1049 \mathrm{pb}$ in duck (GenBank: HM010684.1, 2010). Tsai et al. (2009) proved the complete D-loop mtDNA structure in Columba livia that can be used to identify the mother and genetic linkage.

PCR-RFLP technique is a technique that can multiply certain DNA fragment to figure out whether or not restriction site difference exists in DNA fragment inter individual within one family or population (Griffiiths et al., 2003), which enables to develop as alternative method to analyze genetic diversity and individual genetic uniformity and diversity in native duck population. PCR-RFLP analysis has been well applied to differ species and to detect interspecies or intraspecies variation in some animals like tuna, lobster and swine (Wolf and Hubner, 1999), that has served as verification tool of food product from various animal (Lockley and Bardsley, 2000; Rojas et al., 2011), and is used as well to identify meat characteristic on peacock (Pavocristatus) and other fowl like chicken and turkey (Saini et al., 2007). A mtDNA PCR-RFLP method also identifies genetic diversity in population of wild quail and laboratory quail (Shen et al., 1999), and other fowl species as chicken (Gallus gallus), turkey (Meleagris gallopavo), duck (Anas platyrhynchos) and goose (Anser anser) (Wisniewska and Slota, 2009; Silva et al., 2009).

Research on the effect of plumage color difference in Magelang duck morphology has never been done. In addition, information of identification and molecular genetic diversity using mtDNA $D$-loop region PCR-RFLP analysis of native ducks in all over Indonesia is limited as well. This research aimed to figure out the influence of different plumage colors on morphological diversity of Magelang duck and genetic diversity based on PCR-RFLP mtDNA $D$ loop region analysis of Magelang duck and other native duck populations in Indonesia.

\section{MATERIALS AND METHODS}

Materials used to study morphology diversity were 50 six-month-old Magelang ducks at early production with 11 different plumage colors, namely A. Jarakan polos (plain brown), B. Bosokan (dark brown), C. Klawu blorok (light brown and white), D. Kalung ombo (brown with wide white collar), E. Kalung ciut (brown with thin white collar), F. Cemani (plain black), G. Gambiran (dark brown and white), H. Jarakan kalung (brown with white collar), I. Jowo polos (brown with dark brown spot), J. Wiroko (black and white), K. Plain white (yellow bill and feet). Each color consisted of five ducks, except for A and $\mathrm{B}$, each had 3 and 2 ducks, respectively.

Blood sample was taken from 50 Magelang ducks and 20 were from each native local ducks (Tegal, Mojosari, Bali and Alabio ducks). Chemical reagent used to extract DNA was DNA Isolation Kit (Geneaid). PCR-RFLP analysis used KAPA (Kit PCR), primer Forward (DL-AnasPF), primer Reverse (DL-AnasPR), $\mathrm{dH}_{2} \mathrm{O}$ free nuclease, endonuclease restriction enzyme $A l u \mathrm{I}$ and HaeIII (Thermo Scientific product, Lithuania) and enzyme buffer. Chemicals for agarose gel were agarose powder, buffer 0.5x TBE, good view, loading day and DNA ladder.

The experiment was conducted to figure out (1) morphology diversity and (2) genetic diversity. Morphological diversity was analyzed using Completely Randomized Design (Steel and Torrie, 1980). The treatments were 11 different 
plumage color with 2-5 ducks replicates. The observed variables were (1) egg production, (2) egg weight (g/egg), (3) egg quality comprising egg length and width, egg index, eggshell thickness, albumen and eggyolk weight, albumen height, Haugh Unit (HU) and yolk color, (4) body weight $(\mathrm{g})$, (5) body length $(\mathrm{cm}),(6)$ breast perimeter $(\mathrm{cm})$ and $(7)$ neck length $(\mathrm{cm})$. Body parts measurement was done three times to avoid empirical mistakes of measurement. Egg production and weight was recorded three times and egg quality was randomly observed, in which 10 samples represented each plumage color. Data were analysed with analysis of variance.

Mathematical method used was:

$\mathrm{Y}_{\mathrm{ij}}=\mu+\alpha \mathrm{i}+\varepsilon \mathrm{ij}$

Where $\mathrm{Y}_{\mathrm{ij}}=$ result of observed variables

$\mu=$ mean of population

$\alpha i=$ influence of plumage $i^{\text {th }}$ number

$\varepsilon i j=$ error

Egg production measured was hen day production (HDP), thus the number of egg according to one month of individual record was divided by the number of female ducks times $100 \%$ (Ensminger, 1992), while egg weight was the whole weight of the egg weighed on digital scale with $0.01 \mathrm{~g}$ accuracy. Egg length was the length from the pointed end and obtuse end of egg, while egg width was the distant of 2 sides of egg in the centre, measured with digital slide compass with $0.01 \mathrm{~mm}$ accuracy. Egg index was the comparison of egg width and length times $100 \%$ (Reddy et al,. 1979), while eggshell thickness was measured with digital slide scale from three angles: the pointed end, center and obtuse end of egg, then the score were averaged. Albumen and yolk were separated using egg separator then each weight was scaled and the height was measured with Haugh Unit (HU) (Raymond Haugh, 1937 in Monira et al., 2003). Formula used was: $\mathrm{HU}=100 \mathrm{x} \log \left(\mathrm{h}-1.7 \mathrm{w}^{0.37}\right.$ $+7.6)$.

Where $\mathrm{HU}=$ Haugh Unit

$\mathrm{h}=$ albumen height (in milimeter)

$\mathrm{w}=$ egg weight (in gram)

Yolk color was observed by comparing it to Roche yolk colour fan.

Genetic diversity was analyzed by extracting DNA from duck blood sample and amplifying mtDNA D-loop region with PCR technique and the analysis applied PCR-RFLP. Blood sample was taken using disposible syringe from vena axillaries, then collected in vacuntainer containing
EDTA. Total genome DNA was extracted using Isolation Kit Geneaid according to the protocol. DNA extract was used as PCR template without purification process and resulted in reproducible PCR products. Amplification process of mtDNA $D$-loop region was conducted with primer $D L$ Anas $P F$ (L56) 5' - GTTGCGGGGTTATTTGGTTA3' and DL-AnasPR (H773) 5'CCATATACGCCAACCGTCTC-3', applying GeneAmp ${ }^{\mathrm{R}} \mathrm{PCR}$ system thermocycler 2400 (Perkin Elmer). PCR reagent solution comprised $12.5 \mu \mathrm{K}$ KAPA (Kit PCR), $1 \mu \mathrm{L}$ primer Forward (DL-AnasPF) 10 pmol, $1 \mu \mathrm{L}$ primer Reverse $(D L$ AnasPR) 10 pmol, $9.5 \mu \mathrm{L} \mathrm{dH}_{2} \mathrm{O}$ free nuclease and $1 \mu \mathrm{L}$ DNA template. PCR cycle consisted of predenaturation at $94^{\circ} \mathrm{C}$ for 5 minutes, denatuation at $94^{\circ} \mathrm{C}$ for 30 seconds, annealing at $55^{\circ} \mathrm{C}$ for 45 seconds, elongation (extention) at $72{ }^{\circ} \mathrm{C}$ for 1 minutes and post elongation at $72^{\circ} \mathrm{C}$ for 5 minutes. PCR reaction was repeated 35 times for optimum result. PCR products were separated by electrophoresis in $1.5 \%$ low-melting agarose gel using buffer $0.5 \mathrm{x}$ TBE in Submarine Electrophoresis (Hoefer, USA). RFLP analysis administered PCR products digested with endonuclease restriction enzyme AluI and HaeIII. As much as $1 \mu \mathrm{L}$ endonuclease restriction enzyme added with buffer $\mathrm{R} 2 \mu \mathrm{L}$ and $7 \mu \mathrm{L} \mathrm{dH}_{2} \mathrm{O}$ free nuclease was collected in PCR microtube, then added with $5 \mu \mathrm{L}$ PCR product. The solution was then incubated at $37^{\circ} \mathrm{C}$ overnight for 16 hours. PCR-RFLP analysis result that has been cut with restriction enzyme and undergone electrophoresis in 2\% agar gel then was observed for the DNA band resulted to know the digestion success. DNA band figure in agar gel was taken using digital camera, tabulated then analyzed for the genetic diversity. DNA band obtained from the visualization of agar gel electrophoresis on each sample was then used to determine the haplotype, genetic uniformity and diversity inter Magelang duck and other native ducks. Haplotype diversity obtained showed genetic diversity in Magelang duck and the other native ducks.

\section{RESULTS AND DISCUSSION}

\section{Morphology Diversity in Magelang Duck Population}

This research well demonstrated that plumage color affected $(\mathrm{P}>0.05)$ morphology diversity comprising morphological 
Table 1. Mean and Standard Deviation of Morphological Ccharacteristic in Magelang duck population based on different plumage colors

\begin{tabular}{llccccc}
\hline Code & Plumage Color & $\begin{array}{c}\text { Body Weight } \\
(\mathrm{g})\end{array}$ & $\begin{array}{c}\text { Daily Gain } \\
(\mathrm{g})\end{array}$ & $\begin{array}{c}\text { Neck Length } \\
(\mathrm{cm})\end{array}$ & $\begin{array}{c}\text { Breast } \\
\text { Perimeter } \\
(\mathrm{cm})\end{array}$ & $\begin{array}{c}\text { Body Length } \\
(\mathrm{cm})\end{array}$ \\
\hline $\mathrm{A}$ & Jarakan polos & $1563.33 \pm 221.47$ & $3.29 \pm 2.13$ & $19.33 \pm 0.58$ & $38.33 \pm 1.15$ & $38.33 \pm 1.15$ \\
$\mathrm{~B}$ & Bosokan & $1613.50 \pm 270.82$ & $2.92 \pm 2.29$ & $18.00 \pm 1.41$ & $37.00 \pm 1.41$ & $24.50 \pm 0.71$ \\
$\mathrm{C}$ & Klawu blorok & $1625.00 \pm 101.63$ & $0.40 \pm 2.49$ & $17.40 \pm 1.52$ & $36.40 \pm 1.14$ & $24.60 \pm 1.34$ \\
$\mathrm{D}$ & Kalung ombo & $1837.20 \pm 397.17$ & $5.42 \pm 5.06$ & $17.80 \pm 1.64$ & $37.80 \pm 1.64$ & $23.80 \pm 1.64$ \\
$\mathrm{E}$ & Kalung ciut & $1507.60 \pm 145.67$ & $2.24 \pm 2.52$ & $18.20 \pm 1.30$ & $37.90 \pm 0.89$ & $21.00 \pm 2.34$ \\
$\mathrm{~F}$ & Cemani & $1936.20 \pm 291.82$ & $4.36 \pm 3.04$ & $20.40 \pm 1.67$ & $38.80 \pm 1.30$ & $22.00 \pm 5.10$ \\
$\mathrm{G}$ & Gambiran & $1706.00 \pm 215.03$ & $1.65 \pm 1.56$ & $19.60 \pm 0.55$ & $38.00 \pm 1.73$ & $18.90 \pm 1.67$ \\
$\mathrm{H}$ & Jarakan kalung & $1603.80 \pm 225.80$ & $0.23 \pm 1.24$ & $19.40 \pm 0.55$ & $36.40 \pm 1.29$ & $20.00 \pm 0.71$ \\
$\mathrm{I}$ & Jowo polos & $1412.00 \pm 155.41$ & $4.10 \pm 1.57$ & $17.80 \pm 0.84$ & $36.80 \pm 1.10$ & $18.30 \pm 1.10$ \\
$\mathrm{~J}$ & Wiroko & $1565.60 \pm 250.00$ & $2.04 \pm 2.47$ & $17.40 \pm 0.89$ & $36.20 \pm 1.48$ & $18.40 \pm 0.96$ \\
$\mathrm{~K}$ & Plain white & $1583.20 \pm 87.63$ & $0.42 \pm 1.15$ & $19.80 \pm 0.84$ & $36.40 \pm 1.14$ & $18.80 \pm 0.84$ \\
\hline
\end{tabular}

Table 2. Mean and Standard Deviation of Morphological Characteristic of Egg Production and Quality in Magelang Duck Population with Different Plumage Colors

\begin{tabular}{llcccccc}
\hline Code & Plumage Color & $\begin{array}{c}\text { EP } \\
(\%)\end{array}$ & $\begin{array}{c}\text { EW } \\
(\mathrm{g})\end{array}$ & $\begin{array}{c}\text { EL } \\
(\mathrm{mm})\end{array}$ & $\begin{array}{c}\text { EW } \\
(\mathrm{mm})\end{array}$ & $\begin{array}{c}\text { EI } \\
(\mathrm{mm})\end{array}$ & $\begin{array}{c}\text { ET } \\
(\mathrm{mm})\end{array}$ \\
\hline A & Jarakan polos & $30.37 \pm 23.42$ & $63.45 \pm 1.93$ & $55.14 \pm 0.79$ & $43.70 \pm 0.76$ & $79.26 \pm 2.04$ & $0.40 \pm 0.03$ \\
B & Bosokan & $23.89 \pm 16.50$ & $64.46 \pm 2.59$ & $56.75 \pm 1.07$ & $44.72 \pm 0.77$ & $78.81 \pm 1.43$ & $0.40 \pm 0.04$ \\
C & Klawu blorok & $49.33 \pm 18.78$ & $66.17 \pm 6.41$ & $59.22 \pm 1.67$ & $47.34 \pm 1.06$ & $79.99 \pm 2.48$ & $0.44 \pm 0.03$ \\
D & Kalung ombo & $25.56 \pm 19.29$ & $65.60 \pm 5.82$ & $59.24 \pm 2.00$ & $46.12 \pm 2.21$ & $77.85 \pm 2.88$ & $0.42 \pm 0.04$ \\
E & Kalung ciut & $48.67 \pm 9.41$ & $63.74 \pm 2.83$ & $56.03 \pm 2.33$ & $44.74 \pm 0.66$ & $79.97 \pm 3.40$ & $0.42 \pm 0.01$ \\
F & Cemani & $43.33 \pm 51.51$ & $67.39 \pm 1.12$ & $56.35 \pm 0.93$ & $45.99 \pm 0.61$ & $81.62 \pm 1.12$ & $0.45 \pm 0.06$ \\
G & Gambiran & $33.11 \pm 27.56$ & $64.28 \pm 3.90$ & $54.97 \pm 1.38$ & $45.45 \pm 1.40$ & $82.72 \pm 2.82$ & $0.41 \pm 0.07$ \\
H & Jarakan kalung & $30.56 \pm 29.20$ & $66.72 \pm 1.93$ & $58.02 \pm 0.94$ & $46.33 \pm 0.46$ & $79.88 \pm 1.86$ & $0.43 \pm 0.03$ \\
I & Jowo polos & $35.11 \pm 19.95$ & $58.06 \pm 3.10$ & $53.45 \pm 1.75$ & $44.04 \pm 1.12$ & $82.44 \pm 2.04$ & $0.44 \pm 0.02$ \\
J & Wiroko & $40.22 \pm 32.08$ & $65.32 \pm 2.17$ & $56.34 \pm 2.54$ & $46.07 \pm 0.95$ & $81.87 \pm 2.96$ & $0.51 \pm 0.06$ \\
K & Plain white & $45.56 \pm 12.37$ & $62.34 \pm 1.65$ & $54.26 \pm 2.04$ & $45.23 \pm 0.59$ & $83.46 \pm 3.17$ & $0.42 \pm 0.03$ \\
\hline
\end{tabular}

$\mathrm{EP}=$ Egg Production; EW = Egg eight; EL = Egg Length; EW = Egg Weight; EI = Egg Index ET = Eggshell Thickness 
Table 3. Mean and Standard Deviation of Morphological Characteristic of Albumen and Yolk Quality in Magelang Duck Population with Different Plumage Colors

\begin{tabular}{|c|c|c|c|c|c|}
\hline Code & Plumage Color & $\begin{array}{c}\text { Albumen Weight } \\
(\mathrm{g})\end{array}$ & $\begin{array}{l}\text { Yolk Weight } \\
\text { (g) }\end{array}$ & $\begin{array}{l}\text { Haugh Unit } \\
\text { (mm) }\end{array}$ & $\begin{array}{l}\text { Yolk Color } \\
(\mathrm{mm})\end{array}$ \\
\hline A & Jarakan polos & $27.46 \pm 2.41$ & $22.72 \pm 1.41$ & $66.04 \pm 64.96$ & $5.92 \pm 0.49$ \\
\hline B & Bosokan & $29.06 \pm 1.73$ & $24.09 \pm 2.97$ & $70.95 \pm 18.12$ & $3.88 \pm 0.35$ \\
\hline $\mathrm{C}$ & Klawu blorok & $35.69 \pm 4.17$ & $28.11 \pm 1.54$ & $60.42 \pm 8.65$ & $5.25 \pm 0.35$ \\
\hline $\mathrm{D}$ & Kalung ombo & $35.40 \pm 3.81$ & $23.92 \pm 4.47$ & $66.55 \pm 8.69$ & $5.15 \pm 0.78$ \\
\hline $\mathrm{E}$ & Kalung ciut & $33.03 \pm 2.40$ & $22.87 \pm 2.92$ & $72.69 \pm 7.38$ & $4.91 \pm 0.83$ \\
\hline $\mathrm{F}$ & Cemani & $28.54 \pm 2.01$ & $25.06 \pm 1.30$ & $70.79 \pm 6.54$ & $4.90 \pm 0.57$ \\
\hline G & Gambiran & $29.37 \pm 2.40$ & $24.39 \pm 1.55$ & $58.63 \pm 7.76$ & $4.67 \pm 0.43$ \\
\hline $\mathrm{H}$ & Jarakan kalung & $36.29 \pm 2.12$ & $24.02 \pm 0.93$ & $63.28 \pm 9.02$ & $5.90 \pm 1.10$ \\
\hline I & Jowo polos & $28.96 \pm 2.87$ & $20.79 \pm 1.46$ & $78.07 \pm 8.18$ & $4.10 \pm 0.57$ \\
\hline $\mathrm{J}$ & Wiroko & $32.62 \pm 5.53$ & $20.57 \pm 1.91$ & $66.81 \pm 17.74$ & $5.80 \pm 0.08$ \\
\hline K & Plain white & $30.27 \pm 1.28$ & $24.11 \pm 1.96$ & $63.40 \pm 26.48$ & $4.65 \pm 0.24$ \\
\hline
\end{tabular}

characteristics of body measure (Table 1), egg production (Table 2) and egg quality (Table 3 ) in Magelang duck population.

Many genes determined plumage color pattern and interacted with other genes to determine the phenotype; however, information on the location of gene that controls plumage in specific chromosome was still limited and mechanism underlying this pattern was not absolute either (Stevens, 1991). Color formation of animal's plumage, eyes and skin was affected by melanin pigment and the synthesis is catalyzed by tyrosinase enzyme (Price and Bontrager, 2001 and Liang et al., 2010). Single locus, melanocortin-1 reseptor (MC1R), is responsible to melanic polymorphism. MC1R has various roles among different species (Mundy, 2005). Hormone that limits plumage color expression in most birds is estrogen-dependent found in the females. Mutation point in MC1R and TYRP1 was figured to be responsible to produce pigmentation variants, and TYRP1 expression is lower in the female than in the male (Irwin, 1994). The more frequent plumage color change of the female is mostly due to dichromatism , assuming that sexual selection is more likely to happen to the female's plumage color (Burns, 1998).

This research showed that egg production and its weight was lower but the eggshell thickness was higher (Table 2) than the result of Ismoyowati and Purwantini (2010), reporting that egg production and egg weight of Magelang duck were $70.24 \pm 14.10 \%$ and $69.19 \pm 4.05 \mathrm{~g}$, respectively, and the eggshell thickness was $0.38 \pm 0.02 \mathrm{~mm}$. According to Sofwah (2007), eggshell quality was affected by egg weight and mother's age. This production diversity was influenced by the different of laying period, cage environment, and feed given.

\section{Genetic Diversity in mtDNA $D$-loop region with PCR-RFLP analysis of Magelang Duck and other Native Ducks}

This research was well conducted with PCR amplification of 718-bp fragment. PCR-RFLP analysis result showed that PCR products in mtDNA D-loop region of Magelang duck and the other native ducks were well digested by endonuclease restriction enzyme AluI (Figure 1), proven by different DNA bands size from column 1 to 6. Column 7 showed PCR products and column 8 was DNA markers. AluI-RFLP analysis resulted in four fragment restriction patterns of mtDNA D-loop region, namely pattern I measuring 428, 317, 212, 179 and 119 bp that were obtained from Alabio and Bali duck. Pattern II measured 400, 317, 179 and 119 bp that were 
Table 4. The mtDNA D-loop Region Fragment haplotype of Magelang Duck and Othe Native Ducks Based on Restriction Pattern of AluI and HaeIII Enzyme

\begin{tabular}{lccc}
\hline \multicolumn{1}{c}{$\begin{array}{c}\text { Haplotype } \\
(\text { AluI pattern x HaeIII pattern) }\end{array}$} & \multicolumn{2}{c}{ Fragment Measurements } & \multirow{2}{*}{ Breed } \\
\cline { 2 - 3 } $\begin{array}{l}\text { Haplotipe A } \\
\text { (Pattern I x Pattern I) }\end{array}$ & $428,317,212,179$ and 119 & $460,274,178$ and 166 & Bali \\
$\begin{array}{l}\text { Haplotype B } \\
\text { (Pattern I x Pattern II) }\end{array}$ & $428,317,212,179$ and 119 & 274,178 and 166 & Alabio \\
$\begin{array}{l}\text { Haplotype C } \\
\text { (Pattern II x Pattern I) }\end{array}$ & $400,317,179$ and 119 & $460,274,178$ and 166 & Tegal \\
$\begin{array}{l}\text { Haplotype D } \\
\text { (Pattern III x Pattern II) }\end{array}$ & 400,317 and 179 & 274,178 and 166 & Mojosari \\
$\begin{array}{l}\text { Haplotype E } \\
\text { (Pattern IV x Pattern I) }\end{array}$ & 317,179 and 119 & $460,274,178$ and 166 & Magelang \\
$\begin{array}{l}\text { Haplotype D } \\
\text { (Pattern IV x Pattern II) }\end{array}$ & 317,179 and 119 & 274,178 and 166 & Magelang \\
\hline
\end{tabular}

obtained from Tegal duck. Pattern III measured 400, 317 and $179 \mathrm{bp}$ that were obtained from Mojosari duck. Pattern IV measured 317, 179 and $119 \mathrm{bp}$ that were obtained from Magelang duck. The four patterns showed genetic diversity in at least four native Indonesia ducks based on fragment restriction pattern of mtDNA $D$-loop region by $A l u \mathrm{I}$ enzyme.

Result also showed that PCR products of mtDNA $D$-loop region in Magelang duck and the other native ducks were well digested with HaeIII enzyme (Figure 2) that was proven by different DNA bands size from column 2 to column 7 . Column 8 showed PCR products and column 1 was DNA marker. HaeIII-RFLP analysis resulted in two fragment restriction patterns namely Pattern I measuring $460 \mathrm{bp}, 274 \mathrm{bp}, 178 \mathrm{bp}$ and $166 \mathrm{bp}$ that were obtained from black Cemani of Magelang duck, Tegal duck and Bali duck. Pattern II measured $274 \mathrm{bp}, 178 \mathrm{bp}$ and $166 \mathrm{bp}$ that were obtained from plain white Magelang duck, Mojosari duck and Alabio duck. Both patterns showed genetic diversity in at least two other native Indonesian ducks based on fragment restriction patterns in mtDNA $D$-loop region by HaeIII enzyme.

PCR-RFLP analysis with AluI and HaeIII restriction enzyme resulted in six combinations or restriction patterns, leading to six haplotypes (A,
B, C, D, E and F). Fragment haplotype in mtDNA $D$-loop region of Magelang duck and the other native ducks by $A l u \mathrm{I}$ and HaeIII restriction enzyme is shown in Table 4. Bali duck belongs to haplotype A, Alabio ducks in haplotype B, Tegal duck in haplotype C, Mojosari duck in haplotype $\mathrm{D}$, and Magelang duck in haplotype $\mathrm{E}$ and $\mathrm{F}$. Haplotype diversity showed genetic diversity or marked polymorphism in Indonesian native duck population. Genetic diversity in mtDNA D-loop region existed in different ducks (Magelang, Tegal, Mojosari, Bali and Alabio ducks), although one type of duck (Magelang) showed polymorphism based on maternal inheritance. Hao (2009) studied haplotype diversity (Hd) based on mtDNA D-loop region fragment in Cherry Valley duck in Taiwan. Cherry Valley is classified into two haplotype subgroups, the first homologizes with Mallard duck (Anas zonorhyncha) and Jianchang duck, the second does not homologize or has high variation with Mallard duck.

The difference of restriction pattern shown in research result with PCR-RFLP analysis using restriction enzyme AluI and HaeIII could be clarified by observing polymorphism sequence or nucleotide sequence from mtDNA D-loop region fragment of Magelang duck and other native ducks. Some researchs reported that polymorphism analysis of mtDNA marker 


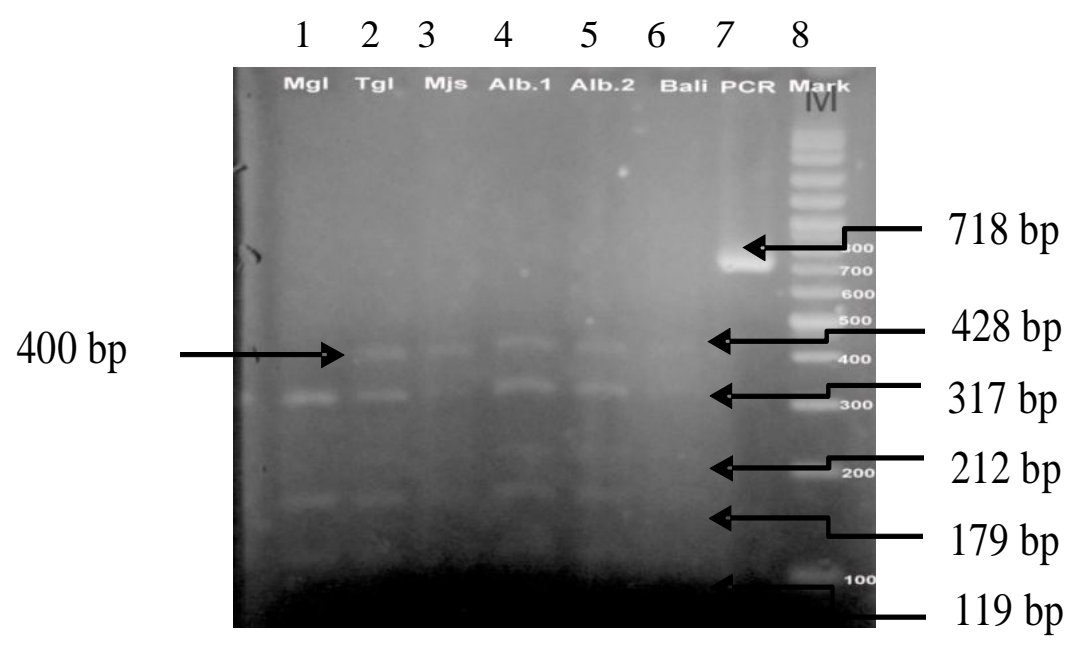

Figure 1. PCR-RFLP Electrophoresis Result of mtDNA D-loop Region Digested with Restriction Enzyme AluI in Magelang Duck (1), Tegal (2), Mojosari (3), Alabio 1 (4), Alabio 2 (5), Bali (6), PCR Products (7) and DNA Marker(8)

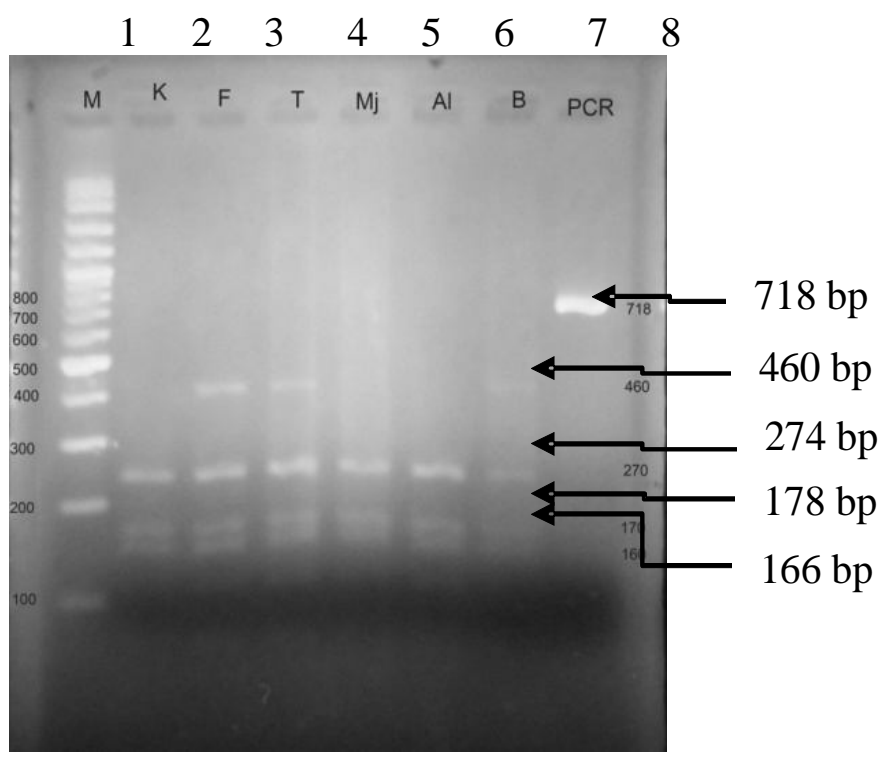

Figure 2. PCR-RFLP Elektrophoresis Result of mtDNA D-loop Region Digested with Restriction Enzyme HaeIII in Plain White Magelang duck (2), black Cemani Magelang duck (3), Tegal Duck (4), Mojosari Duck (5), Alabio Duck (6), Bali Duck (7), PCR products (8) and DNA Marker (1)

included ND1-6, ND4L, COX 1-3, ATP6 and ATP8 in Beijing duck in China (Zhang et al., 2010), prolactin gene polymorphism in purebred China duck (Shanma, Shaoxing, Youma, Jinyun, Jingjiang and interbred (F2) of white Liancheng and white Kaiya) (Wang et al., 2011) and polymorphism of growth hormone gene in Beijing duck, Xihu Mallards, Cherry Valley, Jinding duck, Shan Partridge duck, Jingjiang duck, Shaoxing duck and Partridge Jinyun (Hai et al., 2007) can be done by using PCR-SSCP (Single Stranded Conformation Polymorphism) and the DNA sequencing products.

\section{CONCLUSION}

Plumage color difference affected morphology diversity of Magelang duck 
population, and genetic diversity can be identified using PCR-RFLP in mtDNA D-loop region of Indonesian native duck population.

\section{ACKNOWLEDGMENTS}

The authors would like to express the gratitude to the Directorate General of Higher Education, Ministry of Education and Culture, through Research and Social Service Institute (LPPM) Jenderal Soedirman University for the doctorate program research funding in Postgraduate Program, Animal Science Faculty, Gadjah Mada University Yogyakarta. Sincere gratitude is also addressed to the Dean of Animal Science Faculty, Jenderal Soedirman University for the doctoral study permit.

\section{REFERENCES}

Brown, W.M., M. George and A.C. Wilson. 1979. Rapid evolution of animal mitochondria. Proceedings Natl. Acad. Sci. 76:1967-1971

Burns, K. J. 1998. A phylogenetic perspective on the evolution of sexual dichromatism in tanagers (thraupidae): The role of female versus male plumage. Evolution. 52(4):12191224

Ensminger, M.E. 1992. Poultry Science. $3^{\text {rd }}$ edition. Interstate.Pub, Andville, IL.

GenBank: HM010684.1. 2010. Anas platryrhynchos breed Shaoxing mitochondrion, complete genome.

Griffiths, A.J.E., J.H. Miller, D.T. Suzuki, R.C. Lewontin and W.M. Gilbart. 2003. An Intoduction to Genetic Analysis. $7^{\text {th }}$ Edition. W.H. Freeman and Company, USA.

Hai, X.S., B. W. Bin, C. J. Hua, H. Jun, Z. Hongxiao and C. G. Hong. 2007. Polymorphism analysis on coding and regulation regions of growth hormone gene in duck. Chinese J. Anim. Vet. Sci. 38:907912.

Hao, Y. 2009. Genetic Diversity Analysis of Mitochondrial D-loop Region of Cherry Valley Duck Breed. Journal of Anhui Agricultural Science. 134:279-282

Herman, L. 2004. Species Identification on Poultry Eggs Products. Poult. Sci. 83: 20832085

Ismoyowati and D. Purwantini. 2010. An estimation of genetik variation in Indonesian local duck. Using Microsatellite Marker. Asian J. Poult. Sci. (4):198-204
Irwin, R. 1994. The evolution of plumage dichromatism in the new world blackbirds: Social selection in female brightness? The American Naturalist. 144 (6):890-907

Liang, Z., C. Wang, H. Yu, X. Peng, Y. Feng, Y. Gong and S. Li. 2010. Molecular Cloning, Characterization and Expression Analysis of Duck Tyrosinase-Related Protein-1. J. Anim. Vet. Advances. 9: 2102-2108

Lockley, A.K. and R.G. Bardsley. 2000. DNAbased methods for food authentication. Trends in Food Sci. Technol. 11:67-77

Marzuki, S. 2004. Mitochondrial Medicine: Perspektif Kedepan dalam Mitochondrial Medicine. Lembaga Biologi Molekul Eijkman. Jakarta, pp: 1-16

Monira, K. N., M. Salahuddin and G. Miah. 2003. Effect of Breed and Holding Period on Egg Quality Characteristics of Chicken. International Journal of Poultry Science. 2(4): 261-263

Mundy, N.I. 2005.A window on the genetics of evolution: MC1R and plumage colouration in birds. Proc.Biol. Sci. 2005 Aug 22, 2005. 272(1573):1633-40.

Price, T. and A. Bontrager. 2001. Evolutionary genetics: The evolution of plumage patterns. Current Biology. Vol. 11, Issue 10, 15 May 2001, Pages R405-R408. Department of Biology 0116, University of California at San Diego, La Jolla, California 92093, USA.

Reddy, P. M., V. R. Reddy, C. V. Reddy and P. S. P. Rap. 1979. Egg weight, shape index and hatch ability in Khaki Campbell duck egg. Indian J. Poult. Sci. 14:26-31

Rojas, M., I. Gonzalez, M. A. Pavon, N. Pegels, P.E. Hernandez, T. Garcia and R. Martin. 2011. Mitochondrial and nuclear markers for the authentication of partridge meat and the specific identification of red-legged partridge meat products by polymerase chain reaction. Poult. Sci. 90:211-222

Saini, M., D.K. Das, A. Dhara, D. Swarup, M.P. Yadav and P.K. Gupta. 2007. Characterisation of peacock (Pavocristatus) mitochondrial $12 \mathrm{~S}$ rRNA sequence and its use in differentiation from closely related poultry species. Br. Poult. Sci. 48:162-166

Sakai, R. K., D. H.Delfet, S. Stoffel, S. J. Sharf, R. Higushi, G. T. Horn, K. B. Mulis and H. A. Ehrlich. 1998. Primer Directed Amplification of DNA With a Thermostable DNA Polymerase. Science. 239: 487-491

Shen, X. J., M. Kimura, A. Iwasawa and T. 
Nakamura. 1999. PCR-RFLP Analysis of cytochrom b (cyt b) inheritance in the wildtype strain and laboratory population of Japanese Quail. Res. Bull. Fac. Agr. Gifu Univ. 64:13-20

Sartika, T. 2007. Pembibitan and Peningkatan Mutu Genetik Ayam Lokal. Taksonomi and Asal-Usul Ayam Domestikasi. Keanekaragaman Sumber Daya Hayati Ayam Lokal Indonesia: Manfaat and Potensi. LIPI Press. Jakarta, pp: 105-125

Sigur ardóttir, S., A. Helgason, J.R. Gulcher, Stefanssonk and P. Donelly. 2000. The mutation rate in the human mtDNA control region. Am. J. Hum. Genet. 66:1599-1609

Silva, P., G. Xiaojing, H.S. Olivia, J. Jess, X. Jun, H. Deng, N. David and S Edward. 2009. Mitochondrial DNA-based analysis of genetic variation and relatedness among Sri Lankan indigenous chickens and the Ceylon junglefowl (Gallus lafayetti). J. Anim. Genet. 40(1):1-9

Sofwah, R.H. 2007. Kerabang telur, struktur, komposisi dan faktoryang mempengaruhi kualitasnya. Bulletin C-P. No. 88/VIII/April 2007.

Steel, R.G.D. and J.H. Torrie. 1980. Principles and Procedures of Statistics. McGrawHillBook Co. Inc. New York.

Stevens, L. 1991. Genetics and evolution of the domestic fowl.Departement of Biological and Molecular Sciences University of Stirling.Cambridge University Press. Cambridge. New York Port Chester Melbourne Sydney.
Sudoyo, H. 2004. Polimorfisme DNA Mitokondria and Kedokteran Forensik dalam Mitochondrial Medicine. Lembaga Biologi Molekul Eijkman. Jakarta, pp: 43-55

Tsai, L.C., J.C.I. Lee, S.P. Liao, L.H. Wang, A. Linacre and H.M. Hsieh. 2009. Establishingthe mitochondrial DNA D-loop sructure of Columba livia. Electrophoresis: Emphasis on Proteins and Proteomics. 30 (17):3058-3062

Wang, C., Z. Liang, W. Yu, Y. Feng, X. Peng, Y.Gong and Shijun. 2011. Polymorphism of the prolactin gene and its association with egg production traits in native Chinese ducks. South African J. Anim. Sci. 41:63-69

Wisniewska, M.N and E. Slota. 2009. A new method for species identification of poultry based on 12S-rRNA fragment polymorphism. J. Annals Anim. Sci. (2):127132

Wolf, C., J. Rentsch and P. Hubner. 1999. PCRRFLP analysis of mitochondrial DNA: A reliable method for species identification. J. Agric. Food Chem. 47(4):1350-1355

Zhang, C.L., Y.H. Wang, M. Xie, M. Chen, X.H. Wang and S.S. Hou. 2010. Mitochondrial coding gene polymorphism associated with carcass traits in beijing duck. J. Anim. Vet. Advances. 9:2522-2525.

Zhao, X., N. Li, W. Guo, X. Hu, Z. Liu, G. Gong, A. Wang, J. feng and C. Wu. 2004. Futher evidence for paternal inheritance of mitochondrial DNA in the sheep (Ovis aries). Heridity. 93:399-403 